\title{
Bæredygtig urbanisering og dansk ekspertise
}

\section{Af Peter Taksøe-Jensen}

Verdens bybefolkning vil vokse med omkring 2,7 mia. mennesker frem mod 2050, og mange af de byer i Afrika og Asien, der står til at vokse mest, er allerede nu presset af dårlig infrastruktur, forurening, slum og fattigdom. Men hvis urbaniseringen gribes rigtigt an, kan den blive nøglen til at nå FN-verdensmålene for bæredygtig udvikling. Der skal skabes funktionelle og attraktive rammer for livet i de voksende byer, og Danmark har ekspertise i bæredygtige løsninger, som bør udnyttes.

\section{2007 passerede verden en milepæl.} Antallet af mennesker, som bor i byer, oversteg for første gang i menneskehedens historie antallet af mennesker, der bor på landet. For kun 100 år siden boede to ud af ti af klodens indbyggere i byer. I 1950 var det stadig kun tre ud af ti, som boede i byer. Men i de knap 70 år, der siden er gået, er denne andel næsten fordoblet, og i dag bor omkring 55 pct. af verdens befolkning i byer. På kun 100 år vil udviklingen være vendt helt på hovedet: I 2050 forventes to ud af tre af klodens forventede 9,7 mia. mennesker at bo i byer.

Højindkomstlandene vil i 2030 fortsat udgøre de mest urbaniserede lande, men næsten hele stigningen i den urbane befolkning vil ske i mellem- og lavindkomstlandene, særligt i Asien og Afrika. De to kontinenter vil stå for 95 pct. af væksten. Og op mod 40 pct. af byernes befolkningstilvækst vil ske i blot tre lande - Nigeria (212 mio.), Kina (292 mio.) og ikke mindst Indien (404 mio.).

\section{FN's verdensmål}

Den rivende globale udvikling er baggrunden for, at urbanisering er et af de 17 verdensmål for bæredygtig udvikling, som regeringsledere fra hele verden vedtog i forbindelse med FN-topmødet i New York den 25. september 2015. Det er mål 11: Bæredygtige byer og samfund. Det er opmuntrende, at byer har fået deres eget FN-mål, men nok også på tide.

Verdensmålet om bæredygtige byer betyder, at vi inden 2030 skal sikre alle menneskers adgang til et ordentligt og sikkert sted at bo med basale fornødenheder. Samtidig skal alle have adgang til ordentlige og prismæssigt tilgængelige transportsystemer, og byers negative miljøpåvirkning skal reduceres med bedre luftkvalitet og affaldssystemer. Desuden skal der allerede i 2020 være betydeligt flere byer, der anvender integreret planlægning på områder som social inklusi-

Peter Taksøe-Jensen er Danmarks ambassadør i Indien. 
on, ressourceeffektivitet, nedbringelse af drivhusgasser og klimatilpasning.

Hertil kommer, at FN's 17 verdensmål hænger sammen og indbyrdes understøtter hverandre. Målet om urbaniseringen har blandt andet en tæt sammenhæng med målene om sundhed, rent vand, vedvarende energi, infrastruktur og klimahandling.

Med andre ord udgør urbanisering en emnemæssig prisme for mange af de udfordringer, menneskeheden står overfor i dag. Og Danmark har særlig ekspertise til at tage udfordringen op på mange af områderne. Den hastige urbanisering vil øge efterspørgslen på områder, hvor Danmark generelt står stærkt, såsom vand, energi, sundhed og fødevareteknologi. Også den holistiske og integrerede tilgang til byplanlægning og byudvikling er en dansk kernekompetence.

\section{Klimamålene fra Paris}

FN's 2030-dagsorden er ikke den eneste strategiske ramme for global udvikling, som verdenssamfundet har etableret. Klimaaftalen, der blev vedtaget i Paris i december sidste år, supplerer på en række vigtige områder 2030-dagsordenen, også når det drejer sig om urbanisering.

Det er der en god grund til. Byer er den væsentligste kilde til global opvarmning. Mens verdens byer kun optager tre pct. af jordens landareal, står de for $60-80$ pct. af energiforbruget og 75 pct. af $\mathrm{CO}_{2}$-udledningerne. Klimaforandringer kan få stor betydning for, hvor store økonomiske gevinster det vil lykkes at høste på urbanisering. Det gælder i forhold til temperaturstigninger og det deraf følgende behov for isolering og nedkøling. Det gælder også i forhold til de kraftigere nedbørsmønstre og de hyppigere oversvømmelser og overbelastninger af kloakker og dræn.
Det er i vid udstrækning i byerne kampen mod de globale klimaforandringer står, selvom det var lande og deres regeringer, der skrev under på Paris-aftalen. Og Paris-aftalen indeholder en eksplicit anerkendelse af byers rolle med hensyn til at hjælpe landene med at nå deres forpligtelser.

Det er derfor også opmuntrende at være vidne til, at byer i den industrialiserede del af verden allerede nu arbejder på at sikre, at der sker reduktioner i udledningerne. De pågældende byer har oprettet egne netværk og registre, som de bl.a. kan melde udledningsmål og -reduktioner ind til. Det gælder C40-netværket, som København deltager i, og et andet vigtigt forum, Compact of Mayors, som 26 danske byer deltager i.

Den store udfordring bliver dog at få skabt en kobling mellem landenes reduktionsmål og den konkrete udvikling i navnligt de mindrebemidlede byer verden over, hvor befolkningstilvæksten bliver størst. Det er en kompleks problematik, der omfatter byplanlægning, kapacitet, investeringer og konkrete løsninger. Bottom-up-tilgangen, hvor de enkelte lande selv beslutter, hvor meget de vil reducere deres udledninger - og ikke mindst hvordan - viste klart sin styrke i Paris. Men der er stadig mange spørgsmål knyttet til, hvordan målene i praksis skal opnås.

\section{Bæredygtig urbanisering}

Der er generelt sket en ændring i holdningen til urbanisering blandt politikere og myndigheder. Hvor det tidligere sås som en beklagelig udvikling, der skulle begrænses mest muligt, ser man det nu overvejende som en positiv mulighed om end med store udfordringer. Denne ændring er sket sideløbende med, at det 

menneskers adgang til et ordentligt og sikkert sted at bo med basale fornødenheder.

mange steder i verden rent faktisk er lykkedes at skabe rene, sunde og meget attraktive byer.

Det er også en funktion af den øgede viden, vi i dag har om byer som potentielle kraftcentre for økonomisk udvikling. For det første er produktiviteten højere i byer end på landet - i Asien op mod 5-6 gange. Koncentrationen af kunder giver mulighed for specialisering og dermed højere produktivitet. En lang række erhverv inden for navnlig servicesektoren er slet ikke mulige i mere tyndtbefolkede landdistrikter. Byers befordrende infrastruktur samt sundheds- og uddannelsessystemer i umiddelbar nærhed af produktionen betyder øget produktivitet og innovation. Det samme gælder koncentration af produktion i færre og større enheder, der samtidig betyder mindre forurening.

Det er også billigere at etablere en mere miljø- og sundhedsvenlig infrastruktur i byer, end det er på landet. Alt andet lige falder enhedsomkostninger for tilslutning til og drift af vandforsyning, kloakker og affaldshåndteringssystemer, jo flere der tilsluttes.

\section{Urbanisering kræver styring}

De potentielle økonomiske, sundhedsmæssige og miljømæssige muligheder tabes på gulvet, hvis byer får lov at vokse uden overordnet planlægning og velovervejede investeringer.

På grund af kaotisk ekspansion ('urban sprawl') og manglende infrastrukturinvesteringer hænger mange byer ikke ordentligt sammen, særligt i udviklingslandene. Det gør det ikke kun tids- og ressourcekrævende at bevæge sig fra punkt A til B. Det fordyrer etablering af vandforsyning og kloakker mm., og en stor del af den økonomiske fordel ved byer går tabt.

Et oplagt eksempel er Indien, hvor jeg bor. Mens vandspildet i Danmark i gennemsnit er omkring syv pct., er det fysiske vandspild i Indien over 40 pct. Dertil kommer mangelfuld registrering af vandforbrug og manglende indkrævninger og betalinger. De indiske myndigheder får derfor kun dækket en brøkdel af de betydelige udgifter, de har ved at skaffe rent vand til borgerne.

Sundhed er en af de største udfordringer ved den kaotiske ekspansion af byerne. Når mange mennesker er samlet på et sted med forurening, dårlig infrastruktur og affaldshåndtering samt mangel på kloakering og rent vand, indebærer det en alvorlig trussel for beboernes sundhed. Denne trussel er ikke blevet mindre med globaliseringen, der indebærer en større eksponering over for smitsomme sygdomme. Eksempelvis spreder myggebårne sygdomme som zika, dengue og chikungunya sig for tiden over kloden, særligt i dårligt organiserede og ukloakerede byområder med lækager i ledningsnet etc. Fra 2014 til 2015 oplevede Indien en fordobling af dengue-tilfælde, og langt hovedparten af disse tilfælde var i New Delhi.

Alle erkender vigtigheden af byplanlægning af høj kvalitet. Men andelen af byområder, der opstår spontant, er steget betydeligt de seneste årtier. Mere end 820 millioner mennesker lever i dag i slumkvarterer. Og tallet stiger dagligt. 700 


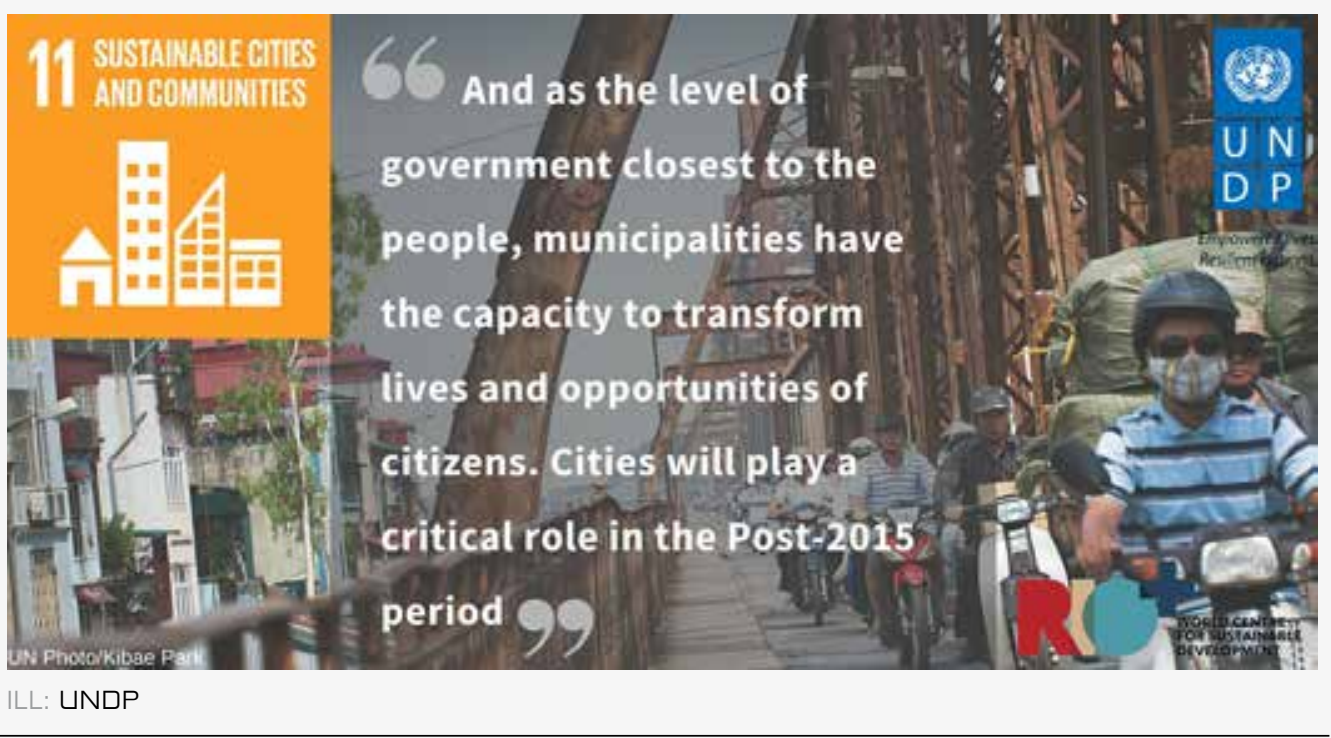

FN's 11. verdensmål om bæredygtige byer og samfund.

mio. byboere verden over har ikke adgang til ordentlige toiletforhold. Ud over den ulykkelige situation, som disse mennesker befinder sig i, er problemet også, at det er vanskeligt at flytte folk.

Når mennesker først har etableret sig et sted, er både de menneskelige og økonomiske omkostninger ved at lave det om mange gange større, end hvis man havde håndteret urbaniseringen rigtigt $\mathrm{i}$ udgangspunktet. Og de ressourcer, der er til rådighed i byer i udviklingslande, bruges i vid udstrækning til lappeløsninger i stedet for holistisk byplanlægning, socialt boligbyggeri og velfungerende infrastruktur.

\section{Manglende ressourcer}

En af de vigtigere barrierer er kapacitet - eller mangel på samme. Ordentlig urbanisering og byudvikling kræver omfattende, helhedsorienteret og gennemtænkt planlægning på basis af avancerede beregninger og fremskrivninger på tværs af sektorer. Det har taget danske administrationer, virksomheder og læreanstalter mange år at oparbejde det ekspertiseniveau, de i dag uomtvisteligt har på området - helt ud i den enkelte kommune. Den kapacitet er kun under opbygning i Afrika og i store dele af Asien. Og jo længere man kommer ud i provinsbyerne, desto større er behovet for at løfte kapaciteten.

En anden barriere er den økonomiske. På sigt betaler urbanisering for sig selv, fordi de værdier, der skabes, er større end de investeringer, der kræves. Men den indledningsvise mobilisering af midler til investeringer er en stor udfordring i udviklingslande. Den manglende kapacitet gør det også vanskeligt at tiltrække finansiering. Problemet er, at mange byer har svært ved at stykke planer, projekter og ansøgninger sammen, der er attraktive for donorer og investorer.

Desuden kræver det ekspertise at tilrettelægge en byudviklingsproces, hvor man gennem $\mathrm{fx}$ beskatning af de ejendomsværdistigninger, der er en funk- 
De potentielle økonomiske, sundhedsmæssige og miljømæssige muligheder tabes på gulvet, hvis byer får lov at vokse uden overordnet planlægning og velovervejede investeringer.

tion af byudviklingen, på sigt kan få de penge tilbage, man investerede. Nye beskatningsformer kan desuden være en politisk udfordring, fx hvis bybefolkningen ikke er vænnet til at betale de reelle omkostninger for de ressourcer, de forbruger såsom vand, sanitet, affaldshåndtering og energi. Kunstigt lave priser medfører ikke kun spild af ressourcer. De gør det også vanskeligt at gøre projekter 'bankable' eller genstand for kommercielle investeringer.

En tredje barriere er det manglende samspil mellem den lange række af administrative niveauer og andre aktører, som skal samarbejde for at sikre en bæredygtig byudvikling. Der skal bygges broer mellem offentlige myndigheder (føderale-, delstats- og by-myndigheder), private aktører (virksomheder, NGO'er, donorer, læreanstalter og forskningsinstitutioner) og internationale organisationer, finansieringsinstitutter $\mathrm{mm}$.

Disse urbaniseringsbarrierer understreger betydningen af et andet af FN's verdensmål. Mål nr. 17 fremhæver behovet for partnerskaber, som skal styrke evnen til at implementere målene. Det drejer sig ikke kun om at styrke evnen til at generere de nødvendige finansielle ressourcer. Det drejer sig også om at opbygge kapacitet lokalt, herunder kapacitet til at generere ressourcer gennem skatter $\mathrm{mm}$. Det omfatter også at forbinde de gode kræfter - myndigheder, virksomheder, NGO'er m.fl. - så de fra deres respektive platforme trækker på en fælles hammel.

Det afspejler en styrket erkendelse af, at ingen enkeltaktør længere er så stærk, at den kan trække os i mål, og at der er en positiv synergieffekt, som kan høstes, når flere forskellige aktører går sammen. De tider er forbi, hvor stater sammen med civilsamfundet alene kan drive udviklingsdagsordenen. $\mathrm{Nu}$ er der behov for en 'whole-of-society' tilgang, hvor alle relevante aktører bringes i spil. Og det er et felt, vi fra dansk side har arbejdet målrettet med.

\section{Danmarks rolle}

Udenrigsministeriet har i de seneste år styrket det økonomiske diplomati, som skal sikre strategiske og værdiskabende indsatser i udlandet, der også understøtter varetagelsen af Danmarks økonomiske interesser. Det sker bl.a. gennem en styrkelse af interministerielt arbejde, tættere inddragelse af erhvervslivet, mere fokus på vækst-og volumenmarkeder, et bedre samspil mellem udviklingsbistand og kommerciel indsats samt bedre adgang for virksomheder til finansiering.

Også på urbaniserings-dagsordenen har økonomisk diplomati en vigtig rolle at spille. Lad os tage Indien som eksempel.

Indien er blandt de lande, der har været relativt sene til at betragte urbanisering som en positiv mulighed. Det er der idelogiske grunde til, der går tilbage til Gandhis vision for et autentisk og uafhængigt Indien. Den fokuserede bl.a. på det værdige og simple landsbyliv frem for det liv, som de industrialiserede byer dengang sås at kunne tilbyde. Ikke desto mindre søgte indere i store tal mod byerne, som imidlertid hverken havde administrativ kapacitet eller midler til at 
håndtere udviklingen. Resultatet er, at mange indiske byer allerede er pressede og således dårligt rustede til at håndtere den kraftige befolkningsvækst, de nu står overfor.

Premierminister Modi lancerede derfor i 2015 en række ambitiøse programmer for udvikling af de indiske byer med ' 100 Smart Cities'-initiativet som spydspidsen. Sideløbende hermed har Modi med sin baggrund som Chief Minister i delstaten Gujarat lanceret en række administrative og finansielle reformer af det føderale system, der skal sikre, at de indiske delstater i højere grad end hidtil bliver i stand til - og ansvarlige for - at skabe økonomisk udvikling og arbejdspladser i deres respektive stater.

Desuden ratificerede Indien den 2. oktober 2016 den globale klimaaftale, der blev indgået i Paris i december 2015. Med en sjettedel af jordens befolkning og det globalt hurtigst voksende forbrug af fossil energi fra 2020 er Indien en væsentlig spiller at få tæt ind i bestræbelserne på at reducere udledning af drivhusgasser. Indien har - i modsætning til Kina - ikke lagt sig fast på, hvor landet vil 'toppe' med hensyn til udledning af drivhusgasser. Man har til gengæld forpligtet sig til en reduktion i landets udledningsintensitet (i forhold til BNP) på 33-35 pct. fra 2005 til 2030. Måske endnu vigtigere har Indien sat som mål, at 40 pct. af landets energi skal komme fra ikke-fossile kilder i 2030.

Men Indien har i dag ikke en effektiv ramme for at arbejde med eksempelvis bygningers energieffektivitet. Og der er udpræget mangel på kapacitet i de led, der skal godkende og monitorere energieffektivt byggeri. 70 pct. af de bygninger og den infrastruktur, Indiens byer vil stå med i 2030, er slet ikke bygget endnu, så bygningers energieffektivitet er strategisk vigtig for Indiens fremtidige energiforbrug og $\mathrm{CO}_{2}$-udledninger.

For ambassaden i New Delhi er det vigtigt at følge udviklingen tæt, fordi myndigheder på delstatsniveau og i byerne bliver en vigtigere flade at arbejde med end hidtil. Konkret er der sket en betydelig overførsel af kompetence, initiativ og penge fra de centrale unionsmyndigheder i Delhi til delstaterne. Denne decentralisering øger efterspørgslen i delstaterne efter afprøvede og effektive løsninger på de mange udfordringer, som de står med inden for områder som vand, affaldshåndtering, fødevarer, logistik, energieffektivisering, infrastruktur. Områder, hvor Danmark har en lang række af kernekompetencer.

Vi har gennem længere tid været aktive på delstatsniveau, navnlig i forhold til Gujarat, som det er lykkedes at opbygge et tæt forhold til bl.a. vedrørende et pilotprojekt inden for vand i byen Rajkot.

\section{Næste skridt}

I efteråret 2015 gik vi skridtet videre og iværksatte en delstatsstrategi, hvor vi mere systematisk afsøgte samarbejds- og erhvervsmuligheder i delstaterne inden for danske styrkepositioner såsom bæredygtige byer, vand, energi(effektivitet) og logistik.

Med den viden i baghånden udvalgte vi delstaterne Rajasthan, Tamil Nadu og

Med en sjettedel af jordens befolkning og det globalt hurtigst voksende forbrug af fossil energi fra 2020 er Indien en væsentlig spiller at få tæt ind i bestræbelserne på at reducere udledning af drivhusgasser. 
I de kommende godt tre årtier vil verdens bybefolkning vokse med omkring 2.7 mia. mennesker. Og urbaniseringen vil hovedsageligt foregå i store udviklingslande i Afrika og Asien, som i vid udstrækning ikke har kapacitet til at håndtere det.

Andhra Pradesh. Og med en bevilling fra $\varnothing \mathrm{K}$ Fonden kunne vi gennemføre Fact Finding-missioner i de tre delstater, nærmere bestemt i byerne Udaipur, Erode og Kakinada, som alle var omfattet af Smart Cities-programmet.

Det bragte os tæt på myndighederne og gav os et værdifuldt førstehåndsindtryk af byernes administrative og kapacitetsmæssige udfordringer, som vi delte med danske virksomheder og andre aktører på et seminar i Asia House i København i maj 2016. Og vi fik vakt den indiske interesse for danske erfaringer og kompetencer. Det kommer helt konkret til udtryk i det planlagte besøg i Danmark i oktober 2016 af den indiske minister for urban udvikling, der har ansvaret for 100 Smart Cities-initiativet.

Desuden etablerede vi i november 2015 en strategisk salgsalliance - 'Smart Liveable Cities Alliance' - sammen med bl.a. Rambøll og Danish Water Forum. Gennem denne alliance er det lykkedes at etablere en direkte dialog mellem de danske virksomheder og repræsentanter for udvalgte bystyrer, så danske kompetencer bliver præsenteret for relevante lokale beslutningstagere.

Endelig arbejder vi på en by-til-by samarbejdsaftale mellem Århus og Udaipur. Den bagvedliggende tanke er at bistå Udaipur med kapacitetsopbygning inden for vand, men aftalen vil også kunne bredes ud til andre områder inden for byplanlægning.

Med denne tilgang er det vores ambi- tion at bidrage til realiseringen af FN's verdensmål og bringe offentlige og private danske kompetencer i spil med henblik på kapacitetsopbygning, så urbaniserings-barriererne nedbrydes. På samme tid varetages Danmarks økonomiske interesser.

\section{Nøglen til bæredygtig udvikling}

I de kommende godt tre årtier vil verdens bybefolkning vokse med omkring 2.7 mia. mennesker. Og urbaniseringen vil hovedsageligt foregå i store udviklingslande i Afrika og Asien, som i vid udstrækning ikke har kapacitet til at håndtere det.

Men urbaniseringen kan være nøglen til at opnå verdensmålene for bæredygtig udvikling såvel som klimamålene. Det kræver, at lande som Danmark med erfaring og stærk kompetence i bæredygtige løsninger kommer på banen og bidrager med en 'whole-of-society'-tilgang allerede tidligt i processen. Og vi skal være opmærksomme på, at byerne bliver til nye økonomiske og politiske magtcentre, som allerede har vist sig ofte at være mere ambitiøse end nationalstaterne, blandt andet på klimaområdet. I dette perspektiv kan en aktiv dansk involvering i urbaniseringen også være med til at etablere nyttige politiske platforme $\mathrm{i}$ fremtidens politiske landskab.

Gribes urbaniseringen rigtigt an, vil det forbedre vores miljø og klima samt milliarder af menneskers liv. 
